\title{
Decision Support System of Fulfillment the Number of Lecturers based on Dikti Form Using Expert System Approach
}

\author{
Azhari. Ali Ridha. \\ Program Magister Universitas Gunadarma, Indonesia \\ Email: azhari.ali@unsika.ac.id \\ Sulistyo Puspitodjati \\ Program Magister Universitas Gunadarma, Indonesia \\ Email: sulistyo@staff.gunadarma.ac.id
}

Received: 20 August 2018; Accepted: 17 October 2018; Published: 08 December 2018

\begin{abstract}
Assessment of education is the standardization imposed by the government to be followed by all universities in Indonesia. Fulfillment of national standards of education aims to ensure quality higher education practices and the quality of its graduates, One of the education practices assessment are assessment of the ratio of lecturers to students. This study aims to help the managerial prepare lecturers to facilitate the process of education and the accreditation process to be faced. Model used with expert system for its inferencing engine with the help of ARIMA forecasting algorithm to predict until the period of accreditation, Forecasting results show the model $(1,1,0)$ which is eligible for prediction.
\end{abstract}

Index Terms - Decision support system, ARIMA, Expert System, Human Resource.

\section{INTRODUCTION}

The problem of decision making is basically a form of selection of various alternative actions that may be chosen which process through a particular mechanism, with the hope that it will produce the best decision. Computer-based information systems are needed, especially in the development of an organization, in this case a university. The fulfillment of the number of lecturers can be done, but this kind of handling will experience many obstacles, especially in terms of accuracy, to be able to overcome it, another system that can handle it is needed to obtain the right and fast information and can overcome the difficulties in managing manually.

As with a higher managerial level, in the process of Universitas Singaperbangsa (UNSIKA) which was established on February 2, 1982, has a vision to become a university that is competitive at the national level in 2020. then the University of Singaperbangsa (UNSIKA) continues to strive to improve the quality of graduates so that they can be competitive. For this reason the
University of Singaperbangsa (UNSIKA) seeks to comply with and fulfill whatever has been outlined by BAN PT to obtain and improve the quality of graduates. Universitas Singaperbangsa (UNSIKA) which has 8 faculties, 2 Post Graduate Programs, 18 study programs has a number of students> 10,000 students. Informatics Engineering study program which was established on June 25, 2008 Based on the regulations on the implementation of higher education, including:

1) Letter of the Director General of Higher Education No. 2920/2007 concerning capacity

2) Higher Education Law No. 12 of 2012

3) Government Regulation Number 4 of 2014 concerning Implementation of Higher Education

4) Minister of Education and Culture Regulation No. 49 of 2014 concerning National Standards for Higher Education the ratio of lecturers / students is 1:25 in general, and updated in 2010 to Science 1:30, and Social 1:45.

Universitas Singaperbangsa Karawang whose status has changed from private universities to state universities face the problem of the availability of lecturers and lecture halls. Of course the change in status from private universities to state universities raises several problems that must be solved, including the problem of availability of lecture halls and lecturers. The growth of the number of students also grew rapidly along with the change in the status of the Singaperbangsa Karawang university. The following is a graph of the number of FASILKOM students at Universitas Singaperbangsa Karawang.

Changes in the status of Universitas Singaperbangsa from the private sector to state University influenced graduates of the high School and Vocational High School especially in the West Java region to register and enter the Singaperbangsa karawang University. The increase in the number of prospective students who want to enter UNSIKA must of course be balanced with the fulfillment of the number of Lecturers and Classrooms in order to 
fulfill the requirements outlined in the Higher Education Form. The following is the number of permanent and non-permanent lecturers at the Fasilkom Universitas Singaperbangsa Karawang.

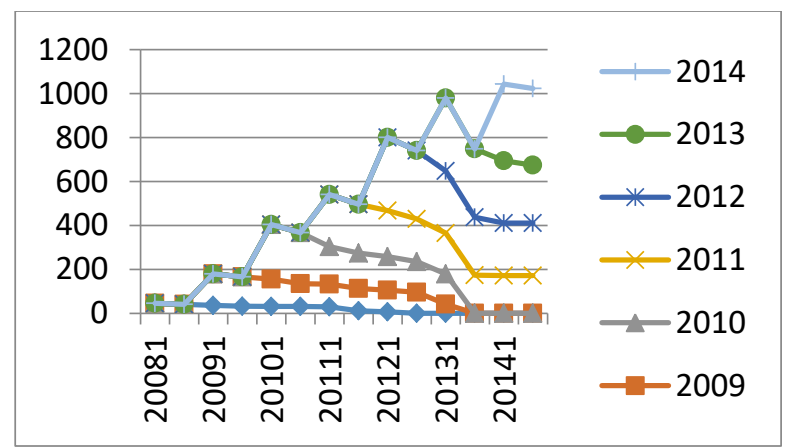

Fig.1. Student growth chart for Fasilkom Unsika

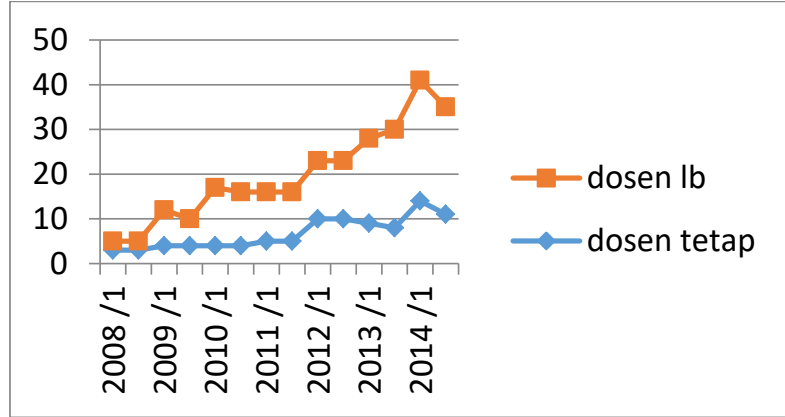

Fig.2. Total Lecturer Fasilkom UNSIKA

The development of fluctuations in the number of lecturers in Fasilkom for their fulfillment must be considered with the number of students and the managerial level that must be taken into account.

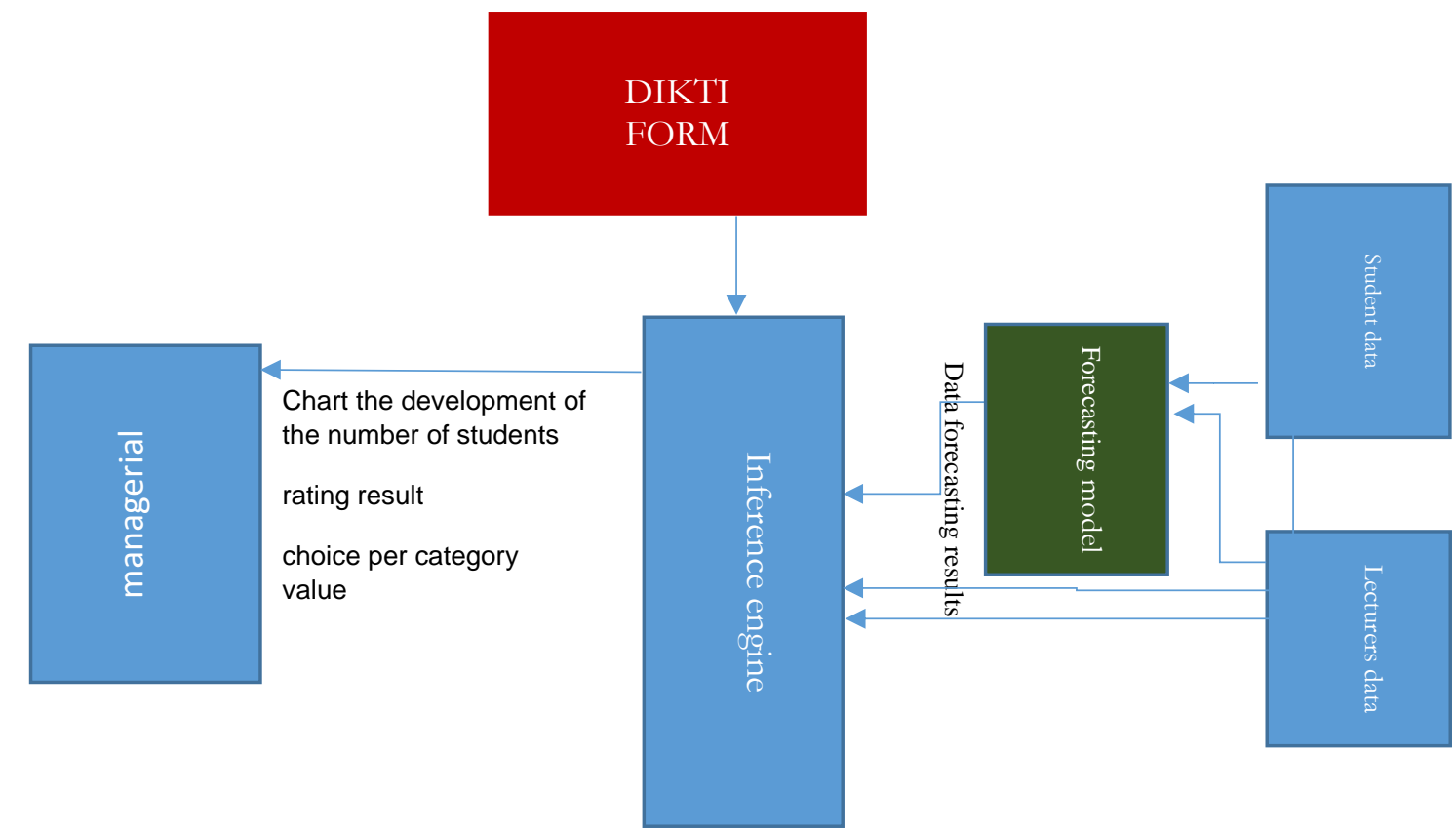

Fig.3. Decision support system for the fulfillment of lecturer

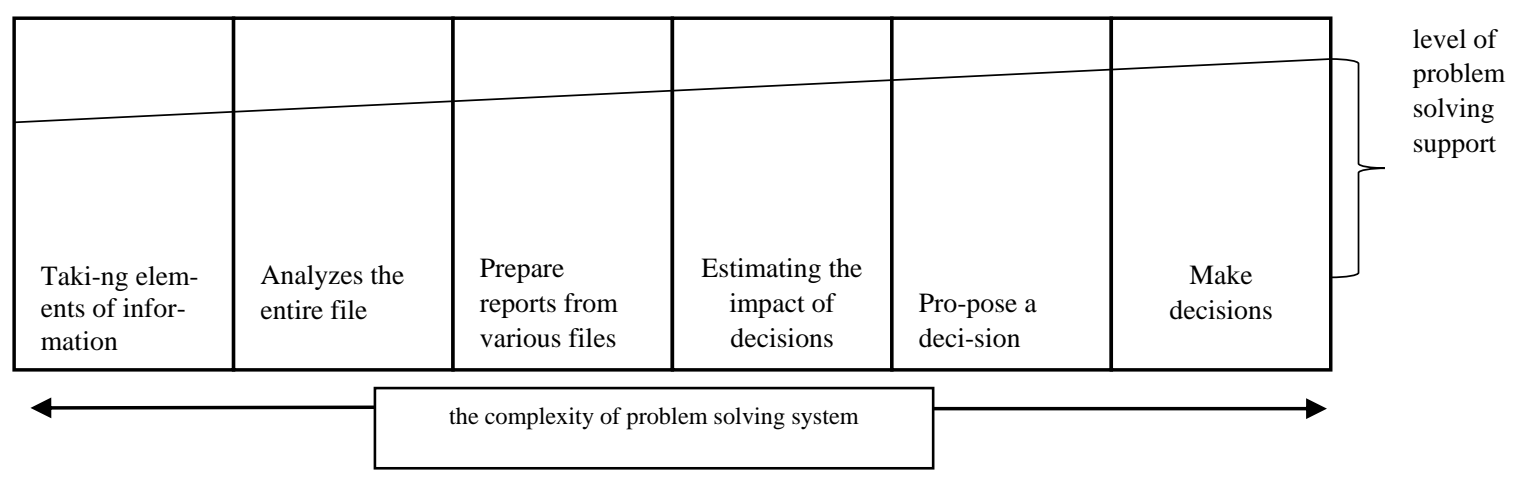

Fig.4. Types of SPK

Figure 3 divided into 3 parts of data, inference engine and managerial display to be used as managerial steps when facing accreditation assessment from the agency Steven L. Alter, at that time a doctoral student at MIT, based on the framework of Gory and Scott Morton conducted a study of 56 decision support systems. This research allows developing a taxonomy and six types of SPK based on the level of problem solving support. The six types are shown in Figure 4. 


\section{Proposed Methedology}

The research design of the number of lecturers' decision support system is based on the forms assessed by the Jenkins box method that will be carried out by the researcher as illustrated as in Figure 3.

In this study will be carried out in several stages in the implementation of which.

\section{Data Collection Process}

In this study, accurate data and information can support the research process. Some data collection methods in this study are::

\section{1) Literature Study}

By conducting a study of expert systems, the box jenkins method and form assessment criteria through literature such as journals, books, scientific sources obtained from the internet with topics related to it.

\section{2) Interview}

Direct interviews with experts on issues taken to obtain accurate data regarding the assessment of the Higher Education Form. The interview process is carried out by conducting question and answer with experts and experts giving the value of the criteria contained in the forms.

\section{RESULTS AND DISCUSSION}

Needs Analysis

In a study forecasting applications meeting the needs of lecturers on the course, using the linear sequential development methods, while the stages are Information System Modeling Is the initial stage in the linear sequential model in which the model will be divided into 2 things

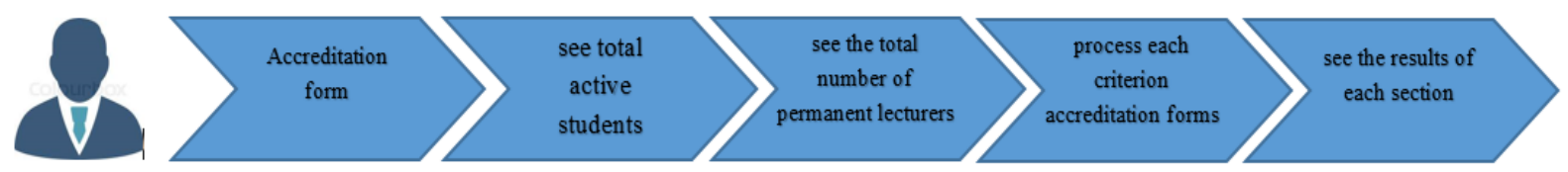

Head of study

\begin{tabular}{|l|l|l|l|l|}
\hline $\begin{array}{l}\text { The Head of } \\
\text { Study examines } \\
\text { the desired item }\end{array}$ & $\begin{array}{l}\text { Collecting the number } \\
\text { of active students on } \\
\text { the semester }\end{array}$ & $\begin{array}{l}\text { Gather the number of } \\
\text { permanent lecturers in } \\
\text { the semester }\end{array}$ & $\begin{array}{c}\text { process each } \\
\text { criterion } \\
\text { accreditation forms }\end{array}$ & $\begin{array}{l}\text { Being in the assessment of how much for this form, } \\
\text { the rating is divided into } 4,3,2,1\end{array}$ \\
\hline $\begin{array}{l}\text { In this study is } \\
\text { devoted to the } \\
\text { needs of lecturers, } \\
\text { namely in point } \\
4.3 .1\end{array}$ & & & & \\
\hline
\end{tabular}

Fig.5. System running

\section{Analysis system runs}

Accreditation preparation system that is running in Fasilkom UNSIKA can be seen in the picture below

\section{1). Problem Analysis}

Analyzing the problem or obstacle experienced by the object of research is by observing the problems for the obstacles that occur when facing the evaluation of accreditation, the analysis is Problems on the head majors

The problems experienced by the head majors are when they will face accreditation assessment when the head majors wants certain grades according to the form in terms of lecturers' needs, the study program head has difficulty determining the number of lecturers in accordance with what should be needed at the teacher's point because the number of students is dynamic per semester

\section{2). Needs Analysis}

After analyzing the problems of the users then needed by the user, i.e : a. The information will be given a forecast conditions at the time the student will be accredited

b. Expert systems will provide the service conditions of students who must possess at the time of the accreditation assessment

c. References in making the proposed addition or subtraction HR lecturers in the study program.

\section{Description of Initial System Functions}

Decision support systems meet the needs of lecturers to help users prepare for the optimal number of lecturers in Higher Education borang assessment, in consultation function will display the amounts that should be prepared by the user to achieve the value in standardized by Higher Education.

Knowledge base consists of two basic elements, namely facts and rules. In this case enter the facts required by the system. In this study focused on HR lecturers where the lecturers are divided into several more criteria, namely permanent lecturers (Dt) 


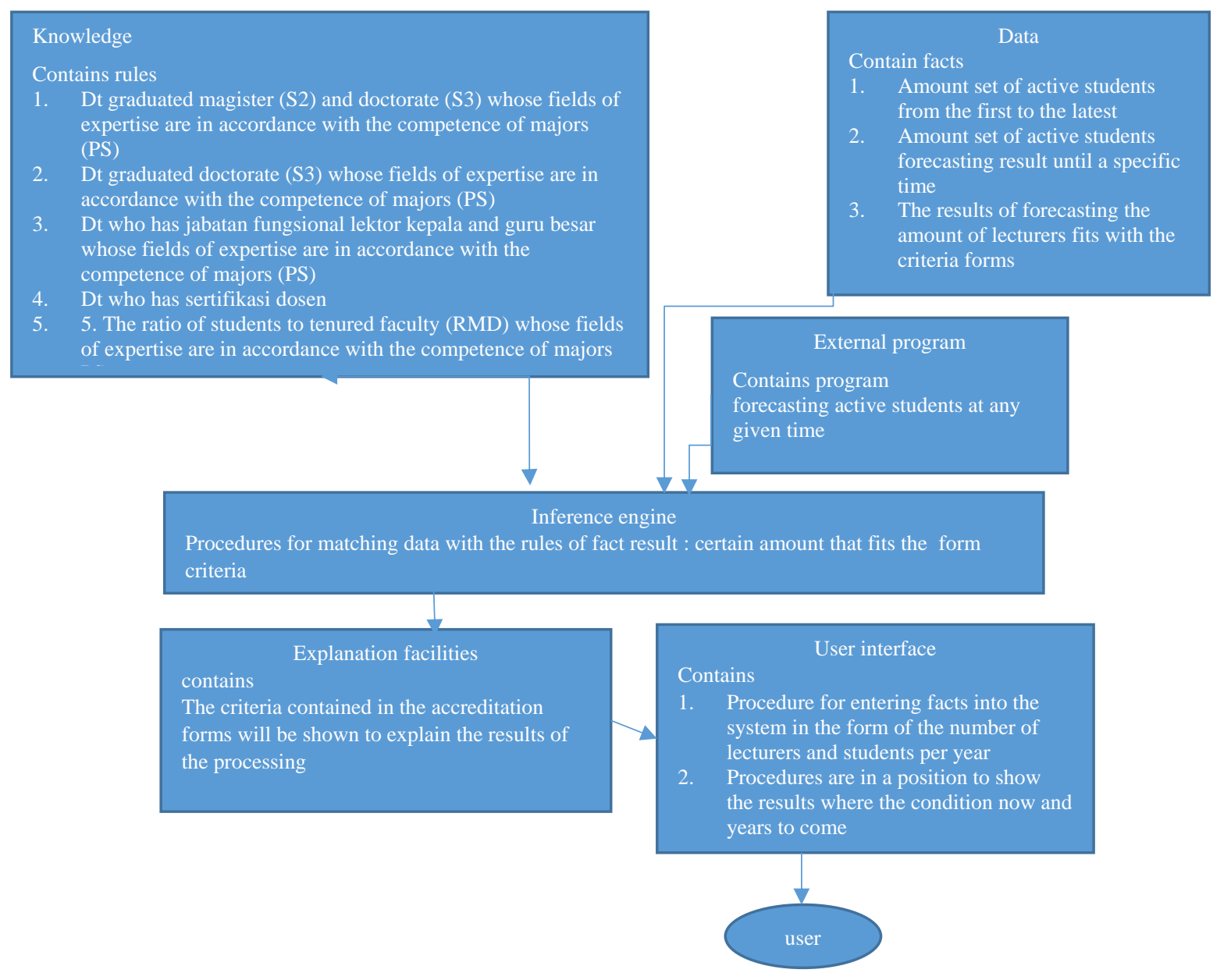

Fig.6. proposed expert system

Table 1. Standard Accreditation forms

\begin{tabular}{|c|c|}
\hline \multirow[t]{3}{*}{ point 1: } & $\begin{array}{ll} & \text { If KD } 1 \geq 90 \% \text {, then score } \\
& =4 .\end{array}$ \\
\hline & $\begin{array}{l}\text { - If } 30 \%<\mathrm{KD} 1<; 90 \% \text {, } \\
\text { then score }=(20 \times \mathrm{KD} 1 / \\
3)-2 .\end{array}$ \\
\hline & $\begin{array}{ll}- & \text { If KD } 1 \leq 30 \% \text {, then score } \\
& =0 .\end{array}$ \\
\hline point 2: & $\begin{array}{ll}- & \text { If KD } 2 \geq 40 \% \text {, then score } \\
& =4 . \\
\text { - } & \text { If } \mathrm{KD} 2<40 \%, \text { then score } \\
& =2+5 \times \mathrm{KD} 2 .\end{array}$ \\
\hline \multirow[t]{2}{*}{ point 3} & $\begin{array}{ll}- & \text { If } \mathrm{KD} 3 \geq 40 \% \text {, then score } \\
& =4\end{array}$ \\
\hline & $\begin{array}{ll} & \text { If KD } 3<40 \%, \text { then score } \\
= & 1+7.5 \times \mathrm{KD} 3\end{array}$ \\
\hline \multirow[t]{2}{*}{ point 4} & $\begin{array}{ll}\text { - } & \text { If } \mathrm{KD} 4 \geq 40 \% \text {, then score } \\
& =4\end{array}$ \\
\hline & $\begin{array}{l}\text { - } \text { If KD } 4<40 \% \text {, then score } \\
=1+7.5 \times \mathrm{KD} 3 .\end{array}$ \\
\hline \multirow[t]{3}{*}{ point 5 (science) } & $\begin{array}{ll}- & \text { If } 17 \leq \mathrm{R} \mathrm{MD} \leq 23, \text { then } \\
& \text { score }=4 .\end{array}$ \\
\hline & $\begin{array}{l}\text { - If } 23<\mathrm{R} M D<60 \text {, then } \\
\text { score }=4 \text { x }(60-\mathrm{R} \mathrm{MD}) / \\
37 . \\
\text { Jika R MD }<17 \text {, then } \\
\text { score }=4 \times \mathrm{R} \mathrm{MD} / 17 \text {. }\end{array}$ \\
\hline & $\begin{array}{ll}\text { - } & \text { Jika } \mathrm{R} M D \geq 60 \text {, then } \\
& \text { score }=0 .\end{array}$ \\
\hline
\end{tabular}

Non-permanent lecturers (dtt) in the assessment point there are rules that are used as a reference

1. Dt graduates master degree and doctorate degree whose expertise is in accordance with the Major competence (KD1)

2. Dt doctorate degree whose expertise is in accordance with the Major competence (KD2)

3. Dt who has jabatan fungsional lektor kepala above (KD3)

4. Dt has sertfikasi dosen (KD4)

5. The ratio of students to permanent lecturers whose fields of expertise are in accordance with major field (R MD)

\section{Data}

The data constructed consists of facts i.e.

1). Total active students

2). Total lecturers

1) Total active student data is taken from the data in the period from the last accreditation to the current condition and active student data at the time of the upcoming accreditation with the help of a forecasting system 
2) The total lecturer data will be in the form of suggestions to users of this data obtained from the student data forecasting results and the total lecturers will be calculated which must be owned by the study program according to the desired assessment criteria

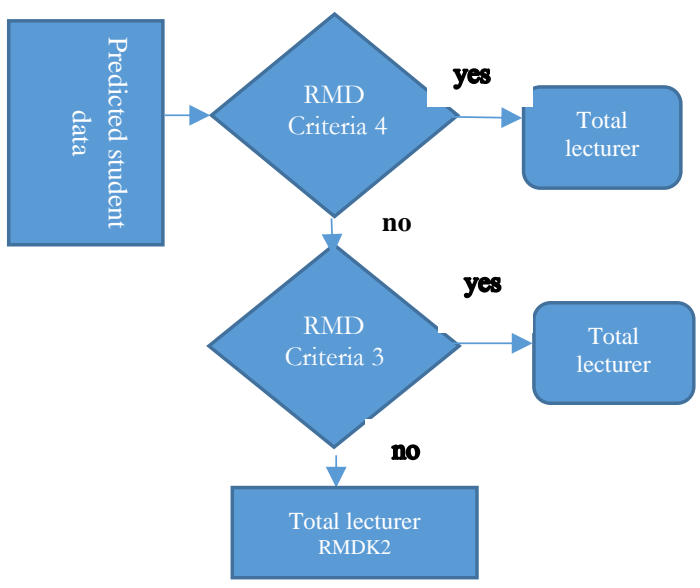

Fig.7. Total permanent lecturers flowchart

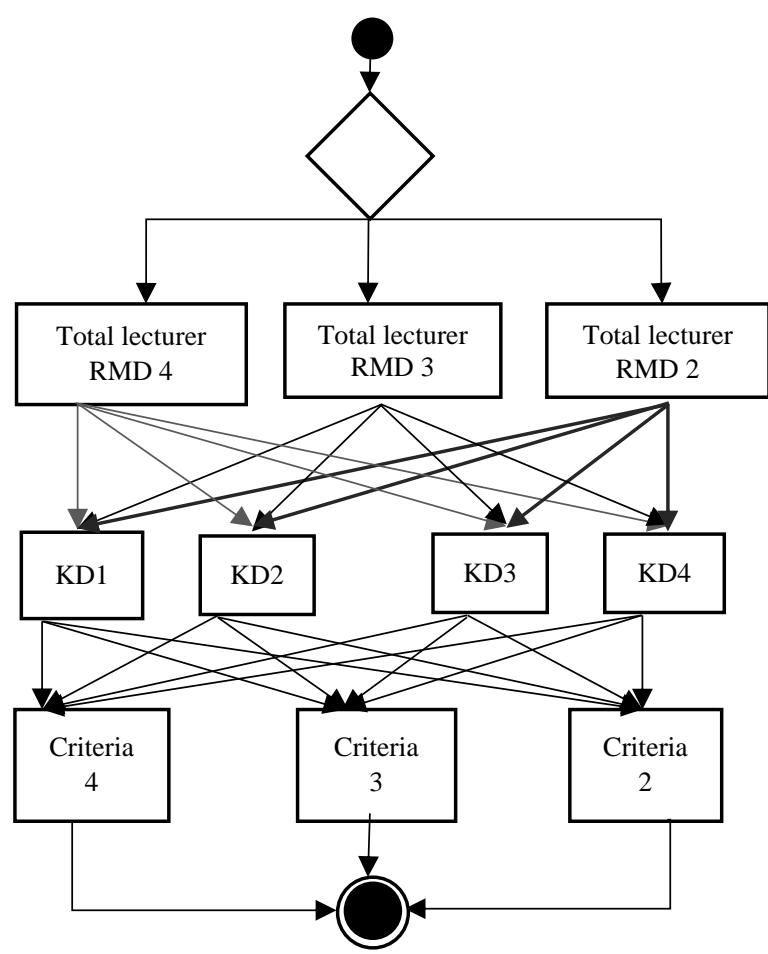

Fig.8. Criteria activity diagram

a. KD1 total forecasting criteria lecturers will be made to the forecasting of lecturers graduated from master and Doctorate

b. KD2 total forecasting criteria lecturers will be made to the forecasting of lecturers graduated from doctorate

c. KD3 total forecasting criteria lecturers will be made to the forecasting of lecturers with jabatan fungsional lektor kepala and above

d. KD4 forecasting criteria lecturers will be made to the forecasting of lecturers with sertfikasi dosen

\section{Inference Engine}

Inference engine will compare the existing data with the rules contained in the form of Higher Education (the assessment of each component is in the respective criteria), then the approach used by the expert system to determine the deficiencies in the assessment starting from the calculation of forecasting of data entered by the user, then processed the forecast will be displayed.

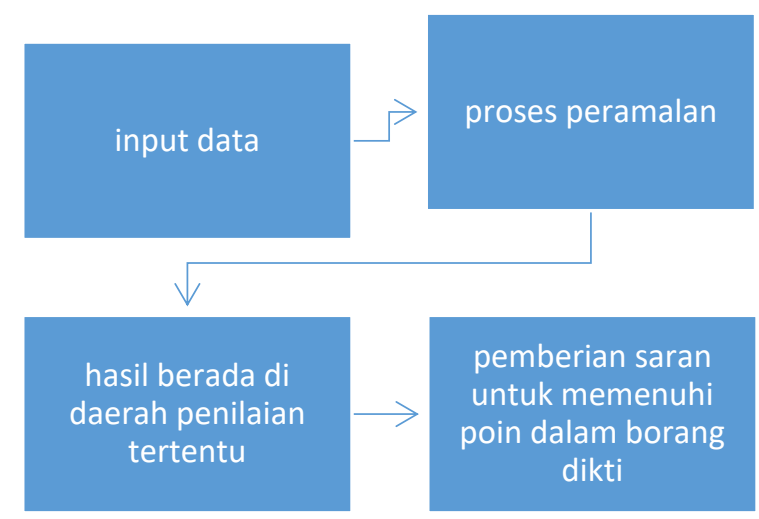

Fig.9. Decision support system flow

a. Input data

This process is to enter the data set that contains the number of students that have been collected from the previous to the present time

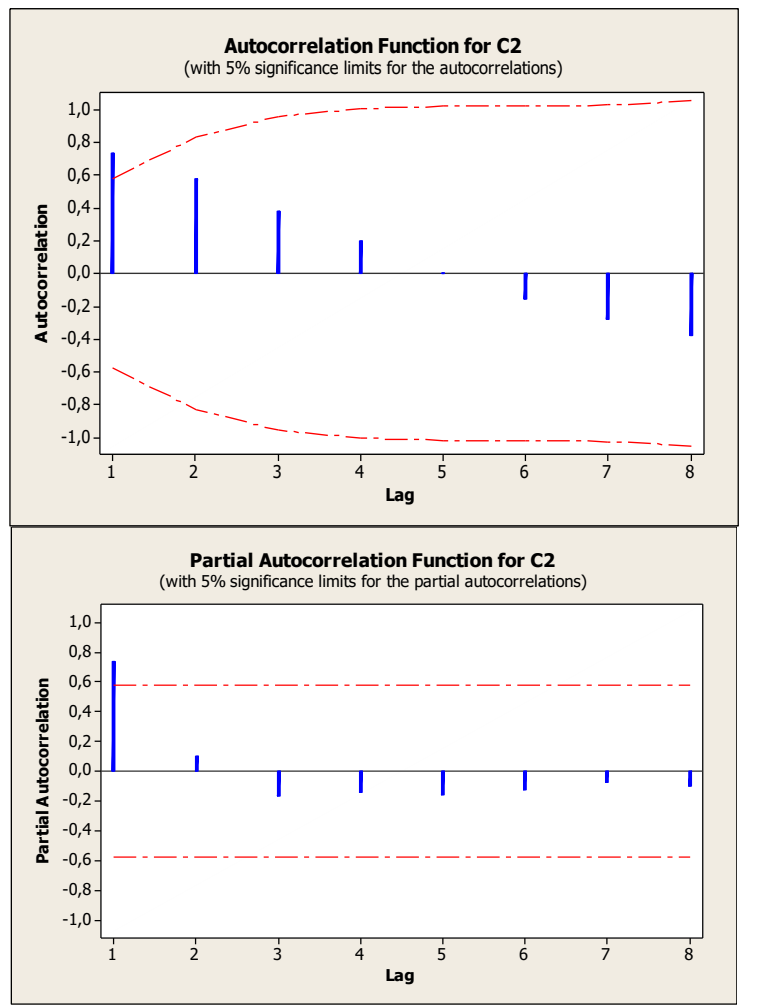

Fig.10. Acf and pacf

b. Forecasting process

This process is to predict the condition of the number of students in a certain period with the 
forecasting methods which in this research using the method ARIMA

\section{ARIMA process}

The first process is to check data stationary using Minitab applications aid the result is

ARIMA $(2,1,0)$ result

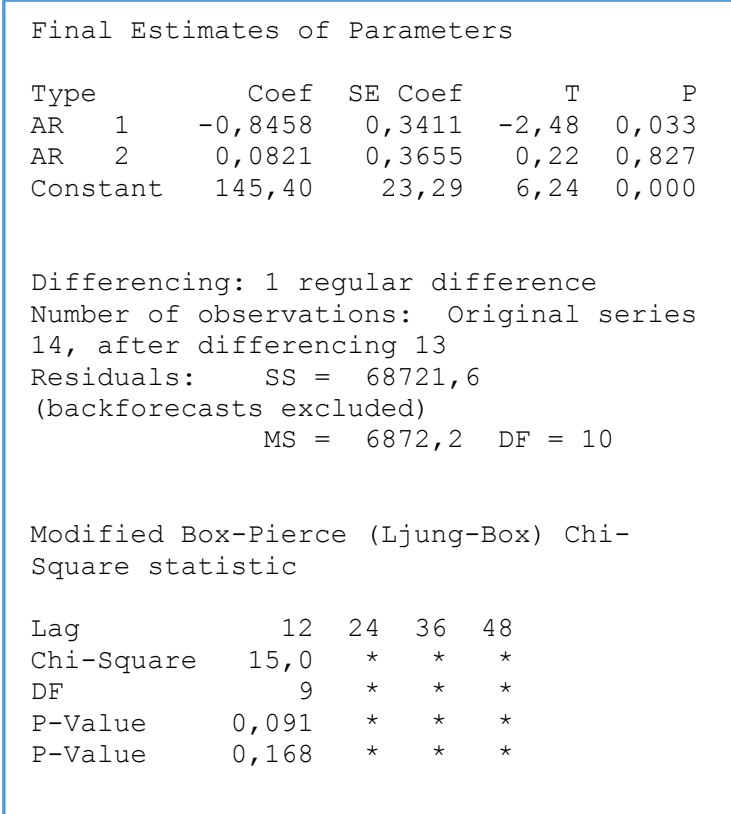

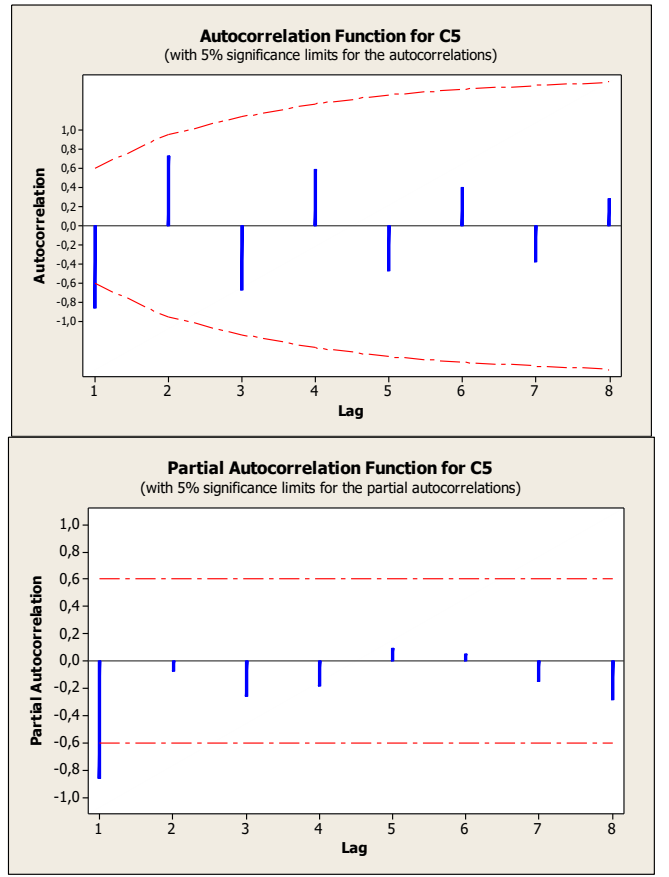

Fig.11 acf dan pacf plot after diferensiated 1
Seen from the acf chart shows down to 0 and continues to decline meaning that data is not stationary to the mean it must be differentiated first. After differentiation 1 , the results of the graph are

c. Forecasting data

Seen the data is stationary against the mean and looks acf cut at lag 1 then ar model 1 and pacf cutin lag 1 then MA model are 1, the model that allows for forecasting are

Table 2. Probability model ARIMA

\begin{tabular}{|c|c|l|}
\hline Model & $\begin{array}{c}\text { Mean Square } \\
\text { Deviation }\end{array}$ & information \\
\hline$A R I M A(1,1,0)$ & 6267,9 & \\
\hline$A R I M A(2,1,0)$ & 6872,2 & \\
\hline$A R I M A(3,1,0)$ & 2372,3 & \\
\hline
\end{tabular}

Result ARIMA $(1,1,0)$

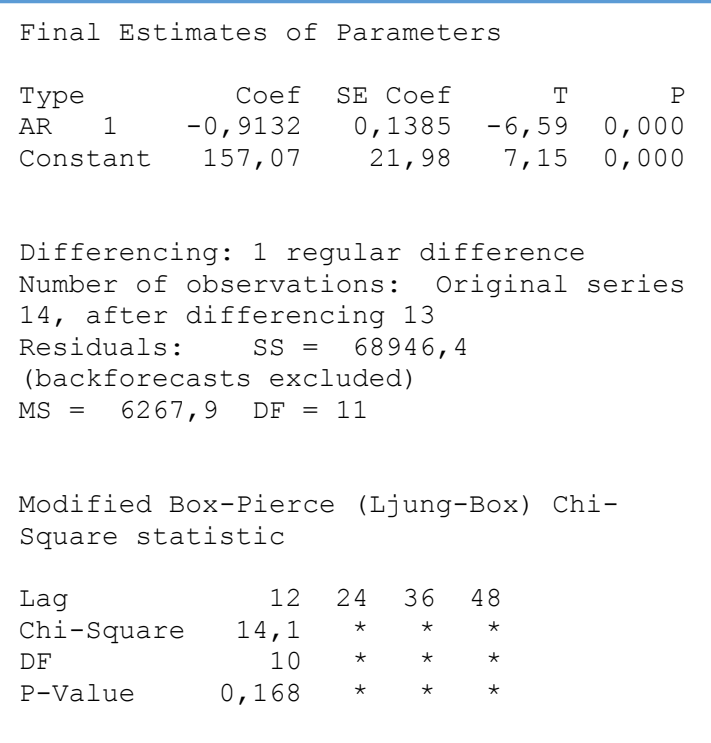

From the test results it is known that in t test, all pvalue $<\alpha$, then all model types have been significant. The error value or MSE of this model is also quite small compared to the testing of the other models, namely 6267.9. From the results of the Box-Pierce (Ljung-box) test, all $p$-value values $>\alpha$, the residual is said to meet the white noise assumption. From this test concluded that the model can be accepted.

For ARIMA 3,1,0

From the test results it is known that in the test, all pvalue values are some that exceed $\alpha$ which is 0.067 . The error value or MSE of this model is 2372.3. From the results of the Box-Pierce (Ljung-box) test, all p-value $>\alpha$ values are said to have not fulfilled the assumption of white noise. From this test concluded that the model cannot be accepted because the value of the $p$ value is not met. 
Then from the 3 models above the model that is more qualified for forecasting is in $\operatorname{ARIMA}(1,1,0)$.

Final Estimates of Parameters
$\begin{aligned} & \text { Type } \\ & \text { P }\end{aligned}$ Coef SE Coef

Final Estimates of Parameters

$\begin{array}{lrrr}\text { Type } & \text { Coef } & \text { SE Coef } & \text { T } \\ \text { P } & & & \\ \text { AR 1 } & -0,9132 & 0,1385 & -6,59 \\ 0,000 & & & \\ \text { Constant } & 157,07 & 21,98 & 7,15 \\ 0,000 & & & \end{array}$

Differencing: 1 regular difference Number of observations: Original series 14, after differencing 13 Residuals: $\quad \mathrm{SS}=68946,4$

(backforecasts excluded)

$\mathrm{MS}=6267,9 \mathrm{DF}=11$

Modified Box-Pierce (Ljung-Box) ChiSquare statistic

$$
\begin{array}{lrrrr}
\text { Lag } & 12 & 24 & 36 & 48 \\
\text { Chi-Square } & 14,1 & * & * & * \\
\text { DF } & 10 & * & * & * \\
\text { P-Value } & 0,168 & * & * & * \\
& & & & \\
\text { Forecasts from period } 14 &
\end{array}
$$

\section{5\% Limits}

$$
\begin{aligned}
& \text { Period Forecast Lower Upper } \\
& \text { Actual } \\
& 151198,34 \quad 1043,13 \quad 1353,54 \\
& 16 \quad 1195,29 \quad 1039,50 \quad 1351,08 \\
& 17 \quad 1355,15 \quad 1143,74 \quad 1566,55 \\
& 18 \quad 1366,23 \quad 1153,39 \quad 1579,07 \\
& 191513,18 \quad 1262,39 \quad 1763,98 \\
& 20 \quad 1536,06 \quad 1282,96 \quad 1789,15 \\
& 211672,24 \quad 1390,36 \quad 1954,12 \\
& 22 \quad 1704,95 \quad 1419,97 \quad 1989,92
\end{aligned}
$$

The Faculty of computer science in Singaperbangsa karawang university will face re-accreditation in 2018 so the data needed to be predicted until that year student data after being processed by the MINITAB helper application is obtained as follows provision of advice to meet Higher Education Higher Education Form accreditation

Table.3. Data on the number of students Fasilkom UNSIKA

\begin{tabular}{|c|c|c|}
\hline year & periode & student \\
\hline 2008 & 1 & 46 \\
\hline & 2 & 41 \\
\hline 2009 & 3 & 180 \\
\hline & 4 & 166 \\
\hline 2010 & 5 & 404 \\
\hline & 6 & 367 \\
\hline 2011 & 7 & 541 \\
\hline & 8 & 496 \\
\hline 2012 & 9 & 800 \\
\hline & 10 & 741 \\
\hline 2013 & 11 & 980 \\
\hline & 12 & 748 \\
\hline 2014 & 13 & 1043 \\
\hline & 14 & 1023 \\
\hline 2015 & 15 & 1198 \\
\hline & 16 & 1195 \\
\hline 2016 & 17 & 1355 \\
\hline & 18 & 1366 \\
\hline 2017 & 19 & 1513 \\
\hline & 20 & 1536 \\
\hline 2018 & 21 & 1672 \\
\hline & 22 & 1705 \\
\hline
\end{tabular}

The following is the calculation process from the point points there are rules that will produce an assessment on the accreditation points, i.e. :

In this process will be divided into 4 processes including.

1). Dt graduated from master and doctorate whose fields of expertise are in accordance with the competence of Major (KD1)

2). Dt, who has a doctorate education whose field of expertise is in accordance with the competence of doctorate (KD2)

3). Dt who has the position of head lector and professor whose expertise is in accordance with the competence of PS (KD3) and Dt who have lecturer certification (KD4)

4). Ratio of students to permanent lecturers whose fields of expertise are in accordance with the field of PS (R MD)

This section is the part in the form that relates to the assessment of the number of lecturers in the study program and each section has its own assessment even though there are items that have the same assessment system.

1). Dt graduated from master and doctorate whose fields of expertise are in accordance with the competence of Major (KD1) 
This section will display suggestions for fulfilling point 4.3.1 form where it will show the movement of the number of students in the study program and will choose the source data from the results of forecasting student lecturer ratio (RMD) to use which criteria and will produce the number of lecturers with master and doctorate education must be fulfilled when the major wants these criteria where the formulation is $\mathrm{KD} 1=$ master and doctorate lecturer / total number of lecturers, the total lecturers are taken from the proposed RMD estimate, for criterion $4 \mathrm{KD} 1=90 \%$, translated to $90 \% *$ $\mathrm{TD}$, for those who do not meet the conditions criterion 4

$$
\begin{aligned}
& \text { Score }=(20 \times \mathrm{KD} 1 / 3)-2 . \\
& \text { Score }+2=20 \times \mathrm{kd} 1 / 3 \\
& \frac{\text { skor }+2}{20}=\frac{k d 1}{3} \\
& \frac{3 x(\text { skor }+2)}{20}=k d 1
\end{aligned}
$$

For 3rd criteria

$$
\frac{3 x(3+2)}{20}=k d 1
$$

above $\mathrm{KD} 1=75 \%$, then for advice lecturers master and doctoral graduates will be annoted $75 \% * \mathrm{TD},(3)$

For 2nd criteria

$$
\frac{3 x(2+2)}{20}=k d 1
$$

Above $\mathrm{KD} 1=60 \%$, then for master and doctoral lecturer advice it translates to $60 \% * \mathrm{TD}$, the result of the calculation of the RMD amount is obtained the value

Table 4. RMD assessment results

\begin{tabular}{|c|c|c|c|c|}
\hline \multicolumn{2}{|c|}{ point KD1 } & criteria 4 & criteria 3 & criteria 2 \\
\hline $90 \%$ & 4 & 68 & 48 & 31 \\
\hline $75 \%$ & 3 & 56 & 40 & 26 \\
\hline $60 \%$ & 2 & 45 & 32 & 20 \\
\hline
\end{tabular}

1). Dt, who has a doctorate education whose field of expertise is in accordance with the competence of major (KD2)

This section will display suggestions for fulfillment of 4.3.2 point items which will show the movement of the number of students in the study program and will select the source data from the results of forecasting student lecturer ratio (RMD) to use which criteria and will produce the number of doctorate educated lecturers (S3) who must fulfilled when the study program wanted these criteria where the formulation, KD2 $=\mathrm{S} 3$ lecturer $/$ total number of lecturers, total lecturers taken from the proposed $\mathrm{RMD}$ estimate, for criteria $4 \mathrm{KD} 2 \geq 40 \%$, if $<40$ then

$$
\begin{gathered}
A-\mathrm{b}=\mathrm{c} \times \mathrm{d} \% \\
d \%=\frac{a-b}{c}
\end{gathered}
$$$$
\text { score }=2+5 \times \mathrm{KD} 2 \mathrm{~A}=\mathrm{b}+\mathrm{c} \times \mathrm{d} \%
$$

For the third criteria is taken from the lower threshold which is in $26,67 \%$, so the total lecturer's suggestion s $3=$ $26,67 \times$ total lecturers

$$
d \%=\frac{3-2}{5}
$$

For the second criteria is taken from the lower threshold which is in 13,33 so the total lecturer's suggestion $\mathrm{s} 3=13,33 \mathrm{x}$ total lecturers

$$
d \%=\frac{2-2}{5}
$$

1). Dt who has the position of lektor kepala and professor whose expertise is in accordance with the competence of major (KD3) and Dt who have lecturer certification (KD4)

This section will display suggestions for fulfilling 4.3.3 and 4.3.4 form items which will show the movement of the number of students in the study program and will select the source data from the results of forecasting student lecturer ratios (RMD) to use which criteria and will produce the number of lecturers have jabatan fungsional (jabfung) lektor kepala (LK) and professors (GB) that must be fulfilled also for assessment for the number of lecturers who have sertifikasi dosen (serdos) so the number of lecturers when the study program wants these criteria where the formulation, KD3 $=$ lecturer jabfung Lk and the professor / total number of lecturers, the total lecturers are taken from the proposed RMD estimates, in the form rules If $\mathrm{KD} 3 \geq 40 \%$, then the score $=4$.

For criterion 4, KD3 and KD4 are needed = total jabfung / total lecturers

Total jabfung $=\mathrm{KD} 3 \mathrm{x}$ total lecturer Total jabfung $=40 \% \mathrm{x}$ total lecturer

If $\mathrm{KD} 3<40 \%$, then the score $=1+7.5 \times \mathrm{KD} 3$.

$$
\begin{gathered}
A=b+c \times d \% \\
d \%=\frac{a}{b+c} \\
d \%=\frac{3}{1+7,5}
\end{gathered}
$$

Criterion 3

For criterion 3 is taken from the lower threshold which is in $32,29 \%$, so the total lecturer's suggestion with jabfung and serdos $=32,29 \times$ total lecturers and do roundup numbers 


$$
d \%=\frac{2}{1+7,5}
$$

\section{Criterion 2}

For criterion 2 taken from the lower threshold of $23.53 \%$, it is recommended total lecturers of Jabfung and Serdos $=23.53 \times$ total lecturers and roundup numbers

4). Ratio of students to permanent lecturers whose fields of expertise are in accordance with the field of major (R MD)

This section will display suggestions for fulfillment of 4.3.2 point items which will show the movement of the number of students in the study program and will select the source data from the results of forecasting student lecturer ratio (RMD) to use which criteria and will produce the number of doctorate educated lecturers who must fulfilled when the study program wants these criteria where the formulation is, For a value of 4 RMD = total student / number of lecturers where the RMD must be between 17 to 23 . For further assessment hsf $=4 \times(60$ - R MD) / 37.4 x (60 - (total students / total permanent lecturers)) / 37. Where the RMD must be between 24 and 60. So it can be formulated

Criteria 4 is targeted to fulfil 23 , the total number of permanent lecturers $=$ student forecast results $(\mathrm{HSF}) / 23$.

With a forecast value of 1705 , for criteria 4 the total lecturers must have 1705/23 = 75 lecturers

Criterion 3 is targeted to fulfil at 32

Criteria value $=4 \times(60-\mathrm{R}$ MD) $/ 37.4 \times(60-\mathrm{RMD}) /$ 37 for mathematical notation

$$
\begin{gathered}
a=b x(c-d) / e \\
\text { axe }=b x(c-d) \\
\frac{a x e}{b}=(c-d) \\
d=c-\frac{a x e}{b}
\end{gathered}
$$

So the recommended RMD is

$$
\begin{aligned}
& d=60-\frac{h s \times 37}{4} \\
& d=60-\frac{3 \times 37}{4}
\end{aligned}
$$

For value 3 must be smaller than the value of $32.2 \%$ for value 2 must be smaller than the value of $41.5 \%$. Furthermore, absolute rounding is done because the object is human and for the total forecast the lecturer is needed

$$
\text { RMD }=\text { hsf } / \text { total lecturer }
$$

Want to where the position of these criteria if you want to 3 then take the maximum number

$$
\begin{aligned}
& \text { Total lecturers }=\text { HSF } / \text { RMD } \\
& \text { Total lecturers }=\text { HSF } / 32.5
\end{aligned}
$$

With a forecast value of 1705 , for criteria 4 the total lecturers must have $1705 / 32.5=53$ lecturers

If you want in 2 then take the maximum number
Total lecturer $=$ HSF $/ 50$

With a forecast value of 1705 , for criteria 4 the total lecturers must have $1705 / 50=34$ lecturers

\section{CONCLUSION}

From the discussion of the results of the analysis that has been described, conclusions can be drawn, namely:

1. The movement of the number of students in the computer science faculty at singaperbangsa karawang university shows a trend and does not have seasonal conditions.

2. This application can be used after the forecast data is calculated using a variety of models.

3 . With the results of forecasting majors director can prepare the number of lecturers needed when accreditation arrives.

4. With the help of the application major director can plan a lecturer career where the lecturer career will be a value in the form

\section{Suggestions}

Based on the results of the analysis in the discussion, suggestions can be given by the author, namely:

1. For researchers who will do the same research, it is recommended to analyze student data with other methods.

2. For future research, the forecasting process can be integrated from the identification of models and adjustments for forecasting and forecasting as a whole with the DSS application

3. For research in the field of academic administration can be integrated with more complex systems in both the application for accreditation or assist in the academic system.

\section{REFERENCES}

[1] E. Sulaeman, E. Suswardji, and Nuraeni, "Jurnal Manajemen Vol.09 No.2 Januari 2012 631,” vol. 09, no. 2, pp. 631-656, 2012.

[2] R. S. Pressman and B. R. Maxim, Software engineering, no. 8. 2014.

[3] I. Pulido-Calvo and M. M. Portela, “Application of neural approaches to one-step daily flow forecasting in Portuguese watersheds," J. Hydrol., vol. 332, no. 1-2, pp. $1-15,2007$.

[4] R. Caballero and T. Go, "An Approach to Multi-Criteria Decision Problems Under Severe Uncertainty," $J$. MultiCriteria Decis. Anal., vol. 2, no. October 2009, pp. 29-48, 2013.

[5] W. Xiuquan, S. Xiaoliu, and T. Zhongfu, "Building a web-based decision support system for sustainable development of energy, economy and environment," 2009 Int. Conf. Signal Process. Syst. ICSPS 2009, May 15, 2009 - May 17, no. 3, pp. 81-84, 2009.

[6] S. Happy and Y. Nainggolan, "Menggunakan metode Analytic Hierarchy Process ( studi kasus: Prodi Manajemen Informatika Politeknik Telkom ) Sistem Pendukung Pengambilan Keputusan Pemilihan Mata Kuliah Pilihan ( studi kasus: Prodi Manajemen Informatika Politeknik Telkom ),”2011. 
[7] A. N. Munawaroh, "Peramalan Jumlah Penumpang Pada Pt. Angkasa Pura I (Persero) Kantor Cabang Bandar Udara Internasional Adisutjipto Yogyakarta Dengan Metode Winter'S Exponential Smoothing Dan Seasonal Arima Skripsi,” Universitas Negeri Yogyakarta, 2013.

[8] I. Braune, A. Pinkwart, and M. Reeg, "Application of multi-criteria analysis for the evaluation of sustainable energy systems - A review of recent literature," in Dubrovnic Conference on Sustainable Development of Energy, Water and Environment Systems, 2009.

[9] A. Udo Richard, Franz, Decision-making support systems Theory \& practice. 2012.

[10] J. Patalas-Maliszewska and T. Krupa, "The Multicriteria Selection Methodology of the Decision Support System," Found. Manag., vol. 2, no. 2, p. 51, 2010.

[11] F. S. Ardina Ariani, Leon Andretti Abdillah, "Sistem pendukung keputusan kelayakan tki ke luar negeri menggunakan fmadm," Fak. Ilmu Komput. Univ. Bina Darma, pp. 336-343, 2011.

[12] E. Turban, J. E. Aronson, and T.-P. Liang, decision support systems and intelligent systems, 7 th ed. prenticehall, 2007.

[13] A. P. Desvina, "Penerapan metode box-jenkins untuk memprediksi jumlah mahasiswa universitas islam negeri suska riau," SiTekIn, vol. 12, no. 1, pp. 80-89, 2014.

[14] J. P. Brans and Y. De Smet, "PROMETHEE methods," Int. Ser. Oper. Res. Manag. Sci., vol. 233, pp. 187-219, 2016.

[15] S. Roman, Access Database Design \& Programming, 3rd Edition, no. January. 2002.

[16] Turban, "Historical Overview of Decision Support Systems (DSS)," Encycl. Inf. Sci. Technol. Second Ed., pp. 1753-1755, 1995

\section{Authors' Profiles}

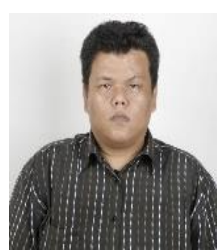

Azhari ali ridha is a lecturer in singaperbangsa karawang university. $\mathrm{He}$ hold diploma in computer science in gunadarma university he is a father of 2 lovely child, his area of interested research is expert system, decission support sytem and system information

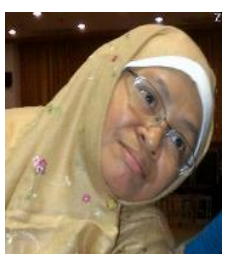

Sulistyo puspitodjati lecturer at gunadarma university. She hold diploma Informatics in STMIK Gunadarma, graduated master in University of New Brunswick, Fredericton and doctorate in informatic Technology in Universitas Gunadarma, her Research Interest are Combinatorial Gray Code and Simulation of volcano eruption disaster mitigation

How to cite this paper: Azhari. Ali Ridha., Sulistyo Puspitodjati, "Decision Support System of Fulfillment the Number of Lecturers based on Dikti Form Using Expert System Approach", International Journal of Modern Education and Computer Science(IJMECS), Vol.10, No.12, pp. 10-19, 2018.DOI: 10.5815/ijmecs.2018.12.02 